\title{
MAŁE TOWARZYSTWA UBEZPIECZEŃ WZAJEMNYCH NA EUROPEJSKIM RYNKU UBEZPIECZENIOWYM - STAN OBECNY I PERSPEKTYWY WYNIKAJĄCE Z DYREKTYWY WYPŁACALNOŚĆ II
}

\section{Wprowadzenie}

Rynek ubezpieczeniowy charakteryzuje się koegzystencją dwóch koncepcji prowadzenia działalności - opartej na idei wzajemności oraz funkcjonującej na zasadach komercyjnych. W teorii i praktyce ubezpieczeń często spotykane jest stwierdzenie, że ubezpieczenia wzajemne stały się archaizmem, że nie ma dla nich miejsca we współczesnym, biznesowym świecie. $Z$ drugiej jednak strony instytucja ubezpieczenia wzajemnego uważana jest za kolebkę ubezpieczeń, odgrywa ważną rolę społeczno-ekonomiczną w systemie współczesnych ubezpieczeń, gromadząc ponad jedną czwartą składki światowego rynku ubezpieczeń ${ }^{1}$.

Towarzystwa ubezpieczeń wzajemnych nie stanowią jednolitej grupy podmiotów gospodarczych. Zarówno tradycja, jak i zachodzące zmiany społeczno-gospodarcze wymusiły ich przekształcanie i dostosowanie się do zmian rynkowych, a w efekcie przybieranie różnorodnych form organizacyjnych². Podstawowym podziałem klasyfikacyjnym TUW w Europie jest ten, który wynika z reżimu prawnego i związany jest $\mathrm{z}$ rozmiarem prowadzonej działalności oraz regulacjami nadzoru. Zgodnie z nim wyróżniamy tzw. małe i duże towarzystwa ubezpieczeń wzajemnych. Spośród ponad

* Uniwersytet Gdański, Wydział Zarządzania.

1 W roku 2012 ubezpieczyciele wzajemni zgromadzili 1,222 bln USD składki, co stanowiło 26,7\% składki na światowym rynku ubezpieczeń. W krajach UE udział ten jest jeszcze większy i w roku 2012 wyniósł 29,6\%. Ubezpieczyciele wzajemni na świecie posiadają 7,7 tryliona USD aktywów, zatrudniają blisko $1,1 \mathrm{mln}$ osób i ubezpieczają ponad $800 \mathrm{mln}$ ubezpieczonych/członków, Global Mutual Market Share 2012, ICMIF 2014, s. 3-31.

2 Zob. M. Janowicz-Lomott, Sytuacja ubezpieczeń wzajemnych na światowym rynku ubezpieczeń, „Prace Naukowe Uniwersytetu Ekonomicznego we Wrocławiu" 2011, nr 175, s. 40-51. 
7 tys. zakładów ubezpieczeń działających w UE, blisko 3 tys. opiera swoją działalność na idei wzajemności, a $3 \%$ posiada status małego TUW ${ }^{3}$.

Celem niniejszego artykułu jest wskazanie cech charakterystycznych i zasad funkcjonowania małego TUW-u w teorii oraz na europejskim rynku ubezpieczeniowym, a także wskazanie szans i zagrożeń w kontekście dyrektywy Wypłacalność II. Opracowanie zawiera analizę krytyczną dorobku literatury polskiej i obcej związanej z tematyką wzajemności ubezpieczeniowej, ze szczególnym uwzględnieniem małego TUW-u, a także analiza regulacji prawnych właściwych małym TUW-om w poszczególnych państwach członkowskich.

Zarówno rozważania teoretyczne, jak i analiza dotychczasowych i przyszłych rozwiązań prawnych wskazują, iż kontynuacja tej formy, zwolnienie jej z reguł nowego systemu wypłacalności i zbudowanie wewnętrznych, krajowych reguł działania małego TUW-u może potencjalnie stać się szansą dla wzajemności ubezpieczeniowej w tej właśnie formie.

\section{Mały TUW na rynku ubezpieczeniowym - specyfika funkcjonowania}

Najbardziej tradycyjna forma prowadzenia działalności ubezpieczeniowej opartej na idei wzajemności zachowała się w małych towarzystwach ubezpieczeń wzajemnych ${ }^{4}$. Za małe towarzystwa ubezpieczeń uważane są zakłady o zakresie działania ograniczonym przedmiotowo, osobowo lub terytorialnie ${ }^{5}$. Niekiedy prawo ogranicza w sposób wyraźny możliwość tworzenia małych towarzystw ubezpieczeń tylko do niektórych działów ubezpieczenia. W małych TUW-ach najlepiej realizowana jest zasada wzajemności ze względu na ograniczony zasięg prowadzonej działalności, a członkowie mają największy wpływ na losy ubezpieczyciela. W małym TUW-ie kluczową rolę odgrywa czynnik osobowy, który pozwala na budowę wspólnoty interesów ${ }^{6}$. Członkowie ubezpieczeni mają możliwość bezpośredniego wpływu na działalność zakładu, między innymi poprzez kształtowanie polityki finansowej czy budowanie strategii rozwoju.

3 Global Mutual Market Share 2012, op.cit., s. 3-5.

4 M. Janowicz-Lomott, Ekonomiczne i społeczne aspekty działalności ubezpieczeniowej opartej na zasadzie wzajemności, Finanse i informatyka w zarządzaniu - wybrane aspekty, „Prace i Materiały Wydziału Zarządzania Uniwersytetu Gdańskiego" 2007, nr 3, 2007, s. 39-53.

5 Podstawy ubezpieczeń, tom III - Przedsiębiorstwo, red. J. Monkiewicz, Poltext, Warszawa 2003, s. 46.

6 M. Kamiński, Ubezpieczenia wzajemne a ubezpieczenia komercyjne, "Rozprawy Ubezpieczeniowe" 2013, nr 15, s. 97-119. 
Analizując podstawowe teorie spotykane w literaturze przedmiotu związane $\mathrm{z}$ funkcjonowaniem na rynku ubezpieczeń zakładów opierających swą działalność na idei wzajemności, warto wskazać przewagi lub też słabości na tym tle małego TUW-u.

Jedną z kluczowych teorii wyjaśniających koegzystencję komercyjnej i wzajemnościowej koncepcji prowadzenia działalności ubezpieczeniowej jest teoria agencyjna głosząca, iż zakłady ubezpieczeń odnoszące sukces w branży to te, których struktura własnościowa pozwala na minimalizację kosztów całkowitych ${ }^{7}$. Teoria agencyjna zwraca uwagę, że całkowity koszt działalności zależny jest zarówno od kosztów produkcji, jak i kosztów agencyjnych. Są to koszty związane z redukcją i rozwiązywaniem konfliktów zachodzących pomiędzy właścicielami, kadrą menedżerską i klientami, powiększone o wartość mocy usługowych utraconych w wyniku niemożności wyeliminowania tych konfliktów ${ }^{8}$.

Rozwiązywanie konfliktów interesów na linii właściciel - menedżer, jest łatwiejsze w zakładach komercyjnych. Akcjonariusze są wspomagani przez analityków i potencjalnych inwestorów oraz mają większe możliwości określenia wartości rynkowej zakładu' . Na TUW-y rynek wywiera znacznie niższą presję niż na podmioty komercyjne. W związku z tym zarząd nie odczuwa efektywnej kontroli rynkowej nad towarzystwem. Szczególnie w strukturze dużych towarzystw, gdzie ulegają podważeniu, a nawet wyeliminowaniu, niektóre właściwości wzajemności ubezpieczeniowej ${ }^{10}$ duża liczba członków i brak ścisłych więzi gospodarczych między nimi powoduje obojętność wobec spraw towarzystwa. Taki indyferentyzm członków sprawia, że czynnikiem decydującym w towarzystwie stać się może de facto kadra kierownicza, dodatkowo pozbawiona kontroli właścicielskiej ${ }^{11}$. Co więcej, często brak jest prawidłowych narzędzi do oceny towarzystw ubezpieczeń wzajemnych ${ }^{12}$. Podmioty zewnętrzne - analitycy czy agencje ratingowe - w swoich ocenach bardzo często nie uwzględniają specyficznych cech towarzystwa ubezpieczeń wzajemnych ${ }^{13}$.

7 Towarzystwa ubezpieczeń wzajemnych $w$ polskim systemie prawnym (stan i perspektywy), red. T. Sangowski, AE Poznań, Poznań 2001, s. 12-13.

8 E.F. Fama, M.C. Jensen, Separation of Ownership and Control, "Journal of Law and Economics" 1983, Vol. 26, s. 301-325.

9 Zob. D. Mayers, C.W. Smith, Ownership structure across lines of property-casualty insurance, "Journal of Law and Economics" 1988, No. 31, s. 353-365.

${ }^{10}$ Są to na przykłady: nierówność praw członków w zakresie decydowania o kluczowych działaniach TUW-u, dopuszczenie inwestorów kapitałowych i udzielenie im praw członkowskich, unikanie sytuacji, w których członkowie uczestniczą w rozdysponowaniu nadwyżki czy pokryciu strat, ubezpieczanie nie członków etc.

${ }_{11}$ Zob. J. Łazowski, Wstęp do nauki o ubezpieczeniach, Lex Wydawnictwo Prawnicze, Sopot 1998, s. 166.

12 Zob. R. Panko, Measuring the Mutuals, "Best's Review (Life/Health Edition)" 1999, s. 51.

13 Zob. M. Convey, No Rating Bias Found Against Mutuals, "National Underwriter" 2000, Vol. 104, No. 40. 
Konflikty na linii właściciel - klient są zaś bardziej widoczne w zakładach komercyjnych. Działania zarządu w komercyjnym zakładzie ubezpieczeń mają przynieść korzyści głównie inwestorom ${ }^{14}$, co znacznie obniża osiąganą w poprzednim punkcie przewagę. W TUW-ie połączony interes właściciela i klienta eliminuje istnienie przeciwstawnych grup nacisku ${ }^{15}$. W małych towarzystwach kontakt członków z towarzystwem jest bezpośredni i na ogół aktywny, członkowie faktycznie zarządzają towarzystwem ${ }^{16}$, zatem ze względu na niższe łączne koszty agencyjne dla średnich i małych towarzystw wzajemnych są one upatrywane jako perspektywiczne dla dalszego rozwoju ubezpieczeń wzajemnych ${ }^{17}$.

W porównaniu do innych form, ubezpieczenia wzajemne, a w szczególności małe TUW-y - charakteryzują się niższym poziomem hazardu moralnego ${ }^{18}$. Mniejsze zagrożenie hazardem moralnym jest związane z tym, że w mniejszej grupie poczucie wspólnoty interesów jest większe niż w dużych i anonimowych zbiorowościach. Bezpośrednia znajomość pomiędzy ubezpieczonymi może też wyraźnie wpływać na obniżenie negatywnej selekcji ${ }^{19}$. Stosunkowo nieduża liczba ubezpieczonych sprawia także, iż przynajmniej część z nich zna się osobiście, a to zmniejsza asymetrię informacji i redukuje prawdopodobieństwo negatywnej selekcji ${ }^{20}$. Zakres samokontroli w małych instytucjach opierających swoje działanie na idei wzajemności jest znacznie większy niż w innych towarzystwach ubezpieczeniowych ${ }^{21}$.

Ważnym problemem spotykanym w organizacji towarzystw ubezpieczeń wzajemnych jest podejmowanie decyzji przez władze złożone z wielu członków lub wielu instancji, co może wiązać się z biurokratycznym formalizmem i niemożnością reakcji. W literaturze ubezpieczeniowej sformułowana została teoria swobody zarządzania, według której TUW-y mogą osiągać lepsze efekty ekonomiczne i przewagę rynkową głównie w rodzajach ubezpieczeń wymagających niższej swobody działania i zezwalających na wolniejsze reakcje towarzystwa na zmiany otoczenia

${ }^{14}$ Choć oczywiście konkurencja na rynku ubezpieczeń narzuca ograniczenia na takie zachowania kierownictwa i właścicieli.

15 J.M. Carson, M.D. Forster, M.J. McNamara, Changes in Ownership Structure: Theory and Evidence from Life Insurers Demutualization, "Journal of Insurance Issues" 1998, Vol. 21, No. 1, s. 2-3.

16 Zob. J. Łazowski, op.cit., s. 166.

17 Por. J.M. Carson, M.D. Forster, M.J. McNamara, op.cit., s. 2-3.

18 Zob. P. Sulewski, E. Majewski, M. Meuwissen, Fundusze ubezpieczeń wzajemnych jako forma ograniczania ryzyka w rolnictwie, „Zagadnienia Ekonomiki Rolnej” 2014, nr 2, s. 127-144.

${ }^{19}$ C. Cafiero, F. Capitanio, A. Cioffi, A. Coppola, Risk and Crisis Management in the Reformed European Agricultural Policy, "Canadian Journal of Agricultural Economics/Revue Canadienne d'agroeconomie" 2007, No. 55, s. 419-441.

${ }^{20}$ Rozumianej jako przystępowania do funduszu osób obarczonych wyższym ryzykiem.

${ }^{21}$ Por. P. Sulewski, E. Majewski, M. Meuwissen, op.cit., s. 133. 
ekonomicznego czy prawnego, a także w ubezpieczeniach o niskiej dynamice szkodowości i jej niedużych wahaniach ${ }^{22}$.

$\mathrm{Z}$ drugiej jednak strony w literaturze przedmiotu podkreśla się zaagnażowanie ubezpieczeń wzajemych w oferowanie ochrony tam, gdzie jest ona trudna, lub w pionierskich obszarach ubezpieczeń, np. rybołówstwo, szkody spowodowane przez dzikie zwierzęta, rolnictwo czy szkody spowodowane błędami w sztuce medycznej. Wyjaśnia się to jednak niższym poziomem hazardu moralnego i negatywnej selekcjii²3.

Jak zatem wynika $z$ analiz, w małych TUW-ach przewagi spowodowane formą organizacyjną opartą na idei wzajemności są nawet wzmocnione w stosunku do dużego, uniwersalnego TUW-u. Ujemną cechą małych towarzystw wzajemnych jest jednak ich „niedoskonałość techniczna”24. Wynika ona przede wszystkim z niewielkiego zasięgu (geograficznego lub liczbowego) ubezpieczeń. Tania administracja i spójność pomiędzy członkami w pewnym stopniu rekompensują ten brak. Jednak pomimo to małe TUW-y są narażone na zachwianie równowagi finansowej i konieczność likwidacji.

\section{Mały TUW w dyrektywach unijnych i regulacjach państw członkowskich}

Podział towarzystw ubezpieczeń wzajemnych związany z rozmiarem prowadzonej działalności na małe TUW i TUW wynika wprost $\mathrm{z}$ dyrektyw unijnych. W regulacjach europejskich już w 1973 r. pojawia się definicja małego TUW-u. Artykuł 3 Pierwszej dyrektywy Rady z dnia 24 lipca 1973 r. w sprawie koordynacji przepisów ustawowych, wykonawczych i administracyjnych odnoszących się do podejmowania i prowadzenia działalności w dziedzinie ubezpieczeń bezpośrednich innych niż ubezpieczenia na życie (73/239/EWG) określa, iż niniejszej dyrektywy nie stosuje się do towarzystw ubezpieczeń wzajemnych, o ile spełniają one wszystkie poniższe warunki:

- statut musi zawierać postanowienia dotyczące wnoszenia dodatkowych wkładów lub zmniejszenia świadczeń,

- ich działalność nie obejmuje ubezpieczenia od odpowiedzialności cywilnej, o ile nie stanowi ono ochrony dodatkowej, ani ubezpieczenia kredytów i poręczeń,

22 Zob. J. Lamm-Tennant, L.T. Starks, Stock Versus Mutual Ownership Structures: The Risk Implications, “The Journal of Business" 1993, No. 66, s. 29-46; D. Mayers, C.W. Smith Jr., Managerial Discretion, Regulation, and Stock Insurer Ownership Structure, "The Journal of Risk and Insurance" 1994, No. 61, s. 638-655.

${ }_{23}$ B.D. Smith, M. Stutzer, A Theory of Mutual Formation and Moral Hazard with Evidence from the History of the Insurance Industry, "Review of Financial Studies"1996, No. 8, 545-577.

${ }^{24}$ Zob. J. Łazowski, op.cit., s. 169. 
- roczny dochód z wkładów z tytułu działalności objętej niniejszą dyrektywą nie może przekroczyć jednego miliona jednostek rozliczeniowych,

- przynajmniej połowa dochodu z wkładów z tytułu działalności objętej niniejszą dyrektywą musi pochodzić od osób będących członkami towarzystw ubezpieczeń wzajemnych.

Oznacza to, że ubezpieczyciele nie muszą przestrzegać wymaganej wypłacalności i innych wymogów ostrożnościowych określonych w dyrektywie, ale w tym samym czasie nie mogą korzystać $\mathrm{z}$ reguł jednolitej licencji ${ }^{25}$. Zapisy Pierwszej dyrektywy zostały zmodyfikowane przez Dyrektywę 2002/13/WE Parlamentu Europejskiego i Rady z dnia 5 marca 2002 r. poprzez podwyższenie granicy przypisu składki do 5 mln EUR rocznych składek.

Wprowadzenie instytucji małego TUW $\mathrm{w}$ regulacjach prawnych miało na celu ułatwienie prowadzenia działalności podmiotom, których rozmiar działania jest znacznie ograniczony i w związku z tym ograniczone są środki finansowe, którymi dysponują. Wymagania prawne i kapitałowe stawiane podmiotom zakładającym towarzystwa ubezpieczeń łagodniej traktują małe towarzystwa ubezpieczeń wzajemnych. Wynika to z konsekwencji rozumienia małego TUW-u jako podmiotu specyficznego, niemającego charakteru handlowego, biznesowego. Wyłączenie małych TUW-ów spod przepisów dyrektyw ubezpieczeniowych spowodowało powstanie w państwach UE narodowych rozwiązań regulujących ich działalność. Regulacje te przebiegają wg czterech podstawowych reguł ${ }^{26}$ :

- regulacje zbliżone do Solvency I (Francja, Polska),

- mix postanowień regulacyjnych (Belgia, Niemcy),

- brak wymogów/regulacji (Szwecja),

- specyficzne regulacje krajowe (Holandia).

Zasady działalności małych TUW-ów we Francji są zbliżone do reguł wynikających z Solvency I. Małymi towarzystwami ubezpieczeń wzajemnych są te, które spełniają warunki zgodne $z$ dyrektywami 73/239/EWG i 2002/13/WE. Małe TUW-y działające wyłącznie w obszarze ubezpieczeń non-life nie muszą spełniać wymogów wypłacalności, jednak wymagane jest posiadanie kapitału początkowego w postaci funduszu organizacyjnego. Rolą tego funduszu jest pokrycie wydatków w pierwszych pięciu latach działalności zakładu i zagwarantowanie realizacji zobowiązań

\footnotetext{
${ }^{25}$ Jednolita licencja zezwala na prowadzenie działalności w dowolnym kraju członkowskim UE bez ubiegania się o zgodę miejscowego nadzoru, jeśli posiada się licencję na prowadzenie działalności w kraju siedziby.

${ }^{26}$ L. Lowett, De Minimis Not Curat Praetor: How the Solvency II Directive Exempts the Very Small Insurers, "Financieel Forum/Bank En Financiewezen" 2010, No. 4, s. 294-297.
} 
towarzystwa ${ }^{27}$. W wypadku TUW-u mającego składkę zmienną minimalna wysokość tego kapitału wynosi 400 tys. EUR w ubezpieczeniach odpowiedzialności cywilnej oraz 240 tys. EUR w pozostałych grupach ubezpieczeń. Kodeks nie ustala minimalnego funduszu początkowego dla TUW pobierającego składki stałe, ale jego poziom musi zostać określony w statucie ${ }^{28}$. Analogicznie określane są wymogi dla małych TUW-ów w Polsce. Mały TUW podlega wpisowi do rejestru, jest zwolniony z wymogów wypłacalności, musi jednak posiadać kapitał początkowy, który zapewni mu bezpieczną początkową działalność. Przeciwnie jednak do wymogów francuskich jego wysokość minimalna nie została określona w przepisach.

Prawo belgijskie zezwala na wyłączenie z obowiązku nadzoru - licencjonowania, spełniania wymogów wypłacalności i sprawozdawczości - jedynie TUW-y działające na obszarze jednej gminy (w której są zgłoszone), ewentualnie z rozszerzeniem do sąsiadujących z nią gmin ${ }^{29}$.

Prawo niemieckie zezwala na wyłączenie małych zakładów ubezpieczeń spod wymogów nadzorczych:

1) na podstawie autonomicznych decyzji władz nadzorczych,

2) na podstawie reguł wynikających z dyrektywy 73/239/EWG.

W Szwecji nie stosuje się uproszczonych wymogów dla małych TUW-ów. Istniały one wcześniej i dotyczyły towarzystw ubezpieczających bydło, ale zostały zlikwidowane ${ }^{30}$.

Oryginalne uproszczone regulacje krajowe dla małych TUW-ów zostały wprowadzone w prawie holenderskim. W Holandii działają trzy kategorie małych TUW-ów majątkowych, które są zwolnione z licencjonowania, nadzoru ostrożnościowego i spełniania wymogów wypłacalności ${ }^{31}$.

Kryteria klasyfikacji TUW-u do odpowiedniej kategorii są oparte na liczbie zawartych polis i rocznym przypisie składki brutto ${ }^{32}$. Trzy wspominane kategorie to (rysunek 1):

- Typ 1 maksymalnie 200 członków i maksymalnie 91 tys. EUR rocznej składki,

- Typ 2 maksymalnie 3 tys. członków i maksimum 455 tys. EUR składki,

\footnotetext{
27 Opisywane reżimy de minimis dotyczą wyłącznie zakładów ubezpieczeń działających na podstawie Kodeksu ubezpieczeniowego Code des assurances, nie dotyczą tzw. mutuelles (organizacji wzajemnościowych), działających przede wszystkim w obszarze ochrony zdrowia i regulowanych przepisami Code de la mutualite.

28 S. Broek, B.-J. Buiskool, A. Vennekens, R. van der Horst, Study on the current situation and prospect of mutual in Europe. Final report, Panteja 2012, s. 36-38.

${ }^{29}$ Mutual Insurance Companies. The regulatory, financial and fiscal arrangements, AISAM 2009, s. 15.

${ }^{30}$ S. Broek, B.-J. Buiskool, A. Vennekens, R. van der Horst, op.cit.

31 Zgodnie $\mathrm{z}$ dekretem Besluit vrijgestelde onderlinge waarborgmaatschappijen,1994.

${ }^{32}$ S. Broek, B.-J. Buiskool, A. Vennekens, R. van der Horst, op.cit.
} 
- Typ 3 - bez maksymalnej liczby członków i maksymalnie 5 mln EUR rocznej składki.

Rysunek 1. Klasyfikacja małych TUW-ów i wymogi ostrożnościowe w Holandii

\begin{tabular}{|c|c|c|c|c|}
\cline { 2 - 5 } \multicolumn{1}{c}{$\begin{array}{c}\text { Prypis składki } \\
\text { EUR0 }\end{array}$} & & \multicolumn{2}{c}{$\begin{array}{l}\text { WYMÓG PEENY } \\
\text { WYMÓG OGRANICZONY }\end{array}$} & $\begin{array}{l}\text { Liczba } \\
\text { ubezpieczonych }\end{array}$ \\
\hline 50000000 & & & Typ 3 & BEZ LIMITU \\
\hline 455000 & & Typ 2 & & $201-3000$ \\
\hline 91000 & Typ 1 & & & $0-200$ \\
\hline
\end{tabular}

Wymagania:

- Nadzór

- Solvency

- Reasekuracja

- Roczne sprawozdanie finansowe

- Statut/regulamin ałożony w nadzorze

Źródło: Mutual insurance in figures, AISAM 2007, s. 57.

Wyłączone spod reżimu prawnego małe TUW-y mają jednak istotnie ograniczone wymogi dotyczące działalności ubezpieczeniowej. I tak ubezpieczyciel typu 1 może prowadzić wyłącznie jedną grupę w ramach ubezpieczeń non-life i nie może to być ubezpieczenie NNW, zdrowotne, odpowiedzialności cywilnej, gwarancje i ubezpieczenia kredytu oraz assistance. TUW-y typu 2 i 3 mogą wprawdzie prowadzić ubezpieczenia w więcej niż jednej grupie ubezpieczeń, ale dotyczą ich te same wyłączenia, co zakłady typu $1^{33}$.

Fakt, że wyżej wymienione kategorie TUW-ów są zwolnione z wymogów ostrożnościowych, nie oznacza jednak, że mogą one działać całkowicie bez kontroli. Aby uzyskać i podtrzymać wyłączenie z nadzoru, poszczególne typy zakładów ubezpieczeń muszą ${ }^{34}$ :

Typ 1: złożyć statut zakładu i informować organ nadzoru o wszelkich jego zmianach, a jeśli pojawiają się zmiany, na żądanie udzielać wszelkich informacji organom nadzoru, w razie konieczności dopuścić kontrolę organu nadzoru.

${ }^{33}$ Mutual insurance in figures, AISAM 2007.

${ }^{34}$ Mutual Insurance Companies. The regulatory, financial and fiscal arrangements, AISAM 2009. 
Typ 2: złożyć statut zakładu i informować organ nadzoru o wszelkich jego zmianach, złożyć roczne sprawozdanie finansowe (bez sprawozdania dotyczącego wypłacalności), złożyć informację reasekuracji prowadzonych ryzyk.

Typ 3: złożyć statut zakładu i informować organ nadzoru o wszelkich jego zmianach, złożyć roczne sprawozdanie finansowe (bez sprawozdania dotyczącego wypłacalności), złożyć informację reasekuracji prowadzonych ryzyk, złożyć raport dotyczący przestrzegania wymogów wypłacalności, przy czym minimalny wymóg kapitałowy wynosi 205 tys. EUR.

W wypadku TUW-ów typu 1 i 2 przepisy dotyczące wypłacalności i związanego $\mathrm{z}$ nią nadzoru nie są stosowane, podczas gdy ubezpieczyciele typu 3, choć zwolnieni są z konieczności uzyskania licencji, to muszą spełniać uproszczone wymogi nadzorcze.

Powyższe uproszczenia stosowane wobec małych TUW-ów niosą ze sobą jednakże konsekwencje związane z odpowiedzialnością pomiędzy zakładem a członkami TUWu. W praktyce istnieją dla małych TUW-ów trzy systemy odpowiedzialności, nie ma jednak korelacji między rodzajem systemu odpowiedzialności i typem zakładu ubezpieczeń. Systemy odpowiedzialności, które muszą zostać określone w statucie, to ${ }^{35}$ :

- TUW z pełną odpowiedzialnością - w wypadku likwidacji TUW-u wszyscy ubezpieczeni członkowie ponoszą odpowiedzialność za zobowiązania zakładu,

- TUW z ograniczoną odpowiedzialnością - w wypadku likwidacji ubezpieczeni członkowie odpowiadają za zobowiązania zakładu wyłącznie do kwoty określonej w statucie,

- TUW zwolniony z odpowiedzialności - w wypadku likwidacji zakładu ubezpieczeni członkowie nie odpowiadają za zobowiązania zakładu.

Analogicznie, wszystkie trzy systemy mogą być stosowane do rozliczania rocznych wyników finansowych TUW-ów. Należy dokonać wyboru między pełną odpowiedzialnością, odpowiedzialnością ograniczoną i brakiem odpowiedzialności ${ }^{36}$. Jeśli wybrana zostanie opcja zwolnienie od odpowiedzialności, nie ma wówczas możliwości ogłaszania dopłat, a odszkodowania są wypłacane jedynie do wysokości funduszy posiadanych przez taki zakład. Jeśli w zakładzie obowiązuje system ograniczonej odpowiedzialności, możliwe jest wezwanie do wniesienia dopłat przez członków ubezpieczonych, jednak takie dopłaty są wówczas ogłaszane tylko na warunkach określonych w statucie i wyłącznie do określonych tam kwot.

Wybór systemu pełnej odpowiedzialności oznacza możliwość ogłaszania nieograniczonych dopłat na warunkach określonych w statucie. Z powodu tych postanowień, ryzyko upadłości małych zakładów wzajemnych jest bardzo ograniczone.

\footnotetext{
${ }^{35}$ Ibidem.

${ }^{36}$ Mutual insurance in figures, AISAM 2007.
} 


\section{Mały TUW a Solvency II}

Zgodnie z regulacjami dyrektywy Solvency II (art. 4), państwa członkowskie mogą wyłączyć z obowiązku stosowania dyrektywy zakłady ubezpieczeń, które spełniają łącznie warunki ${ }^{37}$ :

- roczna składka przypisana nie przekracza 5 mln EUR,

- rezerwy techniczno-ubezpieczeniowe nie przekraczają $25 \mathrm{mln}$ EUR, a jeżeli zakład należy do grupy, łączne rezerwy grupy nie przekraczają $25 \mathrm{mln}$ EUR,

- działalność zakładu nie obejmuje ubezpieczeń lub reasekuracji w zakresie odpowiedzialności cywilnej oraz ryzyka kredytów i poręczeń, chyba że stanowią one ryzyka dodatkowe,

- działalność zakładu w ramach reasekuracji czynnej nie przekracza 0,5 mln EUR składki przypisanej i 2,5 mln EUR rezerw techniczno-ubezpieczeniowych i jednocześnie składka przypisana z reasekuracji czynnej nie przekracza 10\% składki przypisanej, ani 10\% rezerw techniczno-ubezpieczeniowych zakładu.

Jeżeli którakolwiek z kwot określonych powyżej zostanie przekroczona w trzech kolejnych latach, wówczas zakład nie podlega dyrektywie od czwartego roku. Zakłady ubezpieczeń, które mogłyby podlegać wyłączeniu, ale nie chcą, mogą wnioskować o zezwolenie na prowadzenie działalności zgodnie z wymogami Solvency II.

Jednocześnie w punkcie 6 preambuły do dyrektywy uznano prawo państw członkowskich do ustalenia własnych reguł dotyczących rejestracji zakładów wyłączonych z Solvency II czy też objęcia takich zakładów nadzorem ostrożnościowym lub prawnym.

Państwa członkowskie powinny ustanowić własne reguły dotyczące funkcjonowania małych zakładów ubezpieczeń. Do wyboru są cztery opcje:

- zastosowanie reguł Solvency II,

- zastosowanie systemu zbliżonego do Solvency I,

- stworzenie specjalnego systemu krajowego, odmiennego od reguł Solvency I i II,

- brak systemowych regulacji i w efekcie jednakowe traktowanie wszystkich zakładów.

Dyrektywa Solvency II powinna stać się szansą dla państw członkowskich stworzenia własnych reguł ułatwiających działanie małych zakładów ubezpieczeń. Mogą to być (choć nie muszą) zarówno wzajemne, jak i komercyjne zakłady ubezpieczeń.

W projekcie do ustawy o działalności ubezpieczeniowej w Polsce zastosowano rozwiązania analogiczne do dotychczasowych. Mały TUW nie będzie w całości wyłączony z podlegania ustawie, a jedynie niektóre wymogi zostaną wobec niego

\footnotetext{
37 Wszystkie kwoty uwzględniają udział reasekuratorów i spółek celowych oraz są kwotami brutto.
} 
ograniczone. Dotyczy to zasad tworzenia i obniżania kapitału zapasowego oraz jego wysokości minimalnej, obliczania kapitałowego wymogu wypłacalności i posiadania dopuszczonych środków własnych w wysokości nie niższej niż ten wymóg, obliczania minimalnego wymogu kapitałowego i posiadania podstawowych dopuszczonych środków własnych w wysokości nie niższej niż ten wymóg oraz publicznego ujawniania informacji w zakresie opisu zarządzania kapitałem.

W wypadku małych spółek akcyjnych zaplanowano nieco mniej ulg w zakresie stosowania ustawy, bo dotyczą one wyłącznie braku minimalnej wysokości dla kapitału akcyjnego i nieprzekraczalnego dolnego progu minimalnego wymogu kapitałowego.

\section{Podsumowanie}

Regulacje unijne nakładają dużą swobodę, jeśli chodzi o działalność małych TUW-ów. W wielu państwach funkcjonują dla nich specjalne reżimy prawne de minimis. Wprawdzie ubezpieczyciele, uznani za mały TUW, nie mogą korzystać z zasady jednolitej licencji, ale w ich wypadku nie wydaje się to szczególnie istotne. Warto, korzystając z doświadczeń innych państw członkowskich, wprowadzić własne reguły i większą swobodę dla małych TUW-ów także w Polsce. Zwłaszcza, że dyrektywa Solvency II przewiduje możliwość wyłączenia małych zakładów ubezpieczeń z podlegania jej wymogom. Propozycje przedstawione w projekcie ustawy o działalności ubezpieczeniowej nie wydają się wystarczające. Są one skopiowaniem dotychczasowego pomysłu i osadzeniem go w ramach Solvency II (jedynie ze zwolnieniem z niektórych wymogów).

Analiza literatury, ale i doświadczeń wielu państw, wskazuje, że małe TUW-y mogą odnosić sukcesy na rynku ubezpieczeniowym i ich rozwój byłby korzystny dla rynku.

\section{Bibliografia}

Broek S., Buiskool B.-J., Vennekens A., van der Horst R., Study on the current situation and prospect of mutual in Europe. Final report, Panteja 2012.

Cafiero C., Capitanio C., Cioffi F., Coppola A., Risk and Crisis Management in the Reformed European Agricultural Policy, "Canadian Journal of Agricultural Economics/Revue canadienne d'agroeconomie” 2007, No. 55. 
Carson J.M., Forster M.D., McNamara M.J., Changes in Ownership Structure: Theory and Evidence from Life Insurers Demutualization, „Journal of Insurance Issues” 1998, Vol. 21, No. 1.

Convey M., No Rating Bias Found Against Mutuals, „National Underwriter” 2000, Vol. 104, No. 40.

Fama F., Jensen M.C., Separation of Ownership and Control, "Journal of Law and Economics" 1983, Vol. 26.

Global Mutual Market Share 2012, International Cooperative and Mutual Insurance Federation (ICMIF) 2014.

Janowicz-Lomott M., Ekonomiczne i społeczne aspekty działalności ubezpieczeniowej opartej na zasadzie wzajemności. Finanse i informatyka w zarzadzaniu - wybrane aspekty, „Prace i Materiały Wydziału Zarządzania Uniwersytetu Gdańskiego” 2007, nr 3.

Janowicz-Lomott M., Sytuacja ubezpieczeń wzajemnych na światowym rynku ubezpieczeń, „Prace Naukowe UE we Wrocławiu” 2011, nr 175.

Kamiński M., Ubezpieczenia wzajemne a ubezpieczenia komercyjne, "Rozprawy Ubezpieczeniowe" 2013, nr 15.

Lamm-Tennant J., Starks L.T., Stock Versus Mutual Ownership Structures: The Risk Implications, "The Journal of Business" 1993, nr 66.

Łazowski J., Wstęp do nauki o ubezpieczeniach, Lex Wydawnictwo Prawnicze, Sopot 1998.

Lowett L., De Minimis Not Curat Praetor: How the Solvency II Directive Exempts the Very Small Insurers, "Financieel Forum/Bank En Financiewezen" 2010, No. 4.

Mayers D., Smith C.W., Managerial Discretion, Regulation, and Stock Insurer Ownership Structure, "The Journal of Risk and Insurance" 1994, No. 61.

Mayers D., Smith C.W., Ownership structure across lines of property-casualty insurance, „Journal of Law and Economics" 1988, No. 31.

Mutual Insurance Companies. The regulatory, financial and fiscal arrangements, AISAM 2009.

Mutual insurance in figures, AISAM 2007.

Panko R., Measuring the Mutuals, „Best's Review. Life/Health Edition” 1999.

Podstawy ubezpieczeń tom III - Przedsiębiorstwo, red. J. Monkiewicz, Poltext,Warszawa 2003.

Smith BD., Stutzer M., A Theory of Mutual Formation and Moral Hazard with Evidence from the History of the Insurance Industry, "Review of Financial Studies" 1995, No. 8.

Sulewski P., Majewski E., Meuwissen M., Fundusze ubezpieczeń wzajemnych jako forma ograniczania ryzyka w rolnictwie, „Zagadnienia Ekonomiki Rolnej” 2014, nr 2.

Towarzystwa ubezpieczeń wzajemnych $w$ polskim systemie prawnym (stan i perspektywy), red. T. Sangowski, AE Poznań, Poznań 2001. 


\section{Small Mutual Insurance Companies on the European Insurance Market: Current State and Prospects Arising from Solvency II Directive}

All the features of mutuality are most pronounced in small mutuals. This article aims to identify the characteristics and principles of operation of a small mutuals in theory and practice of insurance market. The article also identifies opportunities and threats in the context of Solvency II. Both theoretical considerations and analysis of legal solutions indicate that the continuation of this form, the exemption from the rules of the new solvency system and build internal, national rules of action, could potentially be an opportunity for mutual insurance in the form of a small mutual.

Keywords: small mutual insurance company, de mninimis rules, Solvency I, Solvency II

\section{Les petites mutuelles sur le marché européen de l'assurance - l'état actuel et les perspectives découlant de la directive Solvabilité II}

Toutes les caractéristiques concernant le principe de réciprocité dans l'assurance se manifestent le plus clairement dans les petites entreprises mutuelles d'assurance (TUW). L'article indique les caractéristiques et les principes de leur fonctionnement dans la théorie et la pratique du marché de l'assurance. L'auteur identifie également les opportunités et les menaces dans le cadre de la Solvabilité II. L'analyse théorique et l'analyse des solutions juridiques indiquent que la poursuite de cette forme pourrait être l'occasion pour l'assurance réciproque sous la forme d'une petite mutuelle.

Mots-clés: la petite mutuelle, TUW, la règle de minimis, la Solvabilité I, la Solvabilité II 


\section{Небольшие общества взаимного страхования на европейском страховом рынке: современное состояние и перспективы в связи с введением директивы Solvency II}

Все особенности взаимного страхования наиболее ярко выражены в малых обществах взаимного страхования. Цель статьи представить характеристику и принципы функционирования небольших обществ взаимного страхования в теории и на практике. Статья также определяет возможности и угрозы, связанные с директивой Solvency II. Теоретическое соображения и анализ правовых регулирований показывают, что продолжение этой формы, освобождение от правил новой системы платежеспособности и создание внутренних, национальных правил деятельности, могут стать шансом для взаимного страхования в виде небольших обществ взаимного страхования.

Ключевые слова: небольшие общества взаимного страхования, правила de minimis, Solvency I, Solvency II 